\title{
Treatment with Venetoclax for Chronic Lymphocytic Leukemia with the Highest Known White Blood Cell Count: Safe and Effective
}

\author{
Bilinen En Yüksek Beyaz Küre Sayılı Kronik Lenfositik Lösemi için Venetoclax ile Tedavi: \\ Güvenli ve Etkili
}

(D) Mehmet Sönmez, (DD Merve Kestane, (D) Osman Akıdan, (D) Nergiz Erkut, (D) Özlen Bektaş

Karadeniz Technical University Faculty of Medicine, Department of Hematology, Trabzon, Turkey

\section{To the Editor,}

Venetoclax is a potent, selective inhibitor of B-cell lymphoma 2 (BCL-2) that is a key regulator of apoptosis and is used for the management of chronic lymphocytic leukemia (CLL) either alone or in combination. Inhibition of BCL-2 induces apoptosis, leading to rapid tumor debulking and high response rates in cases of CLL. The toxicity profile of venetoclax includes manageable hematologic toxicities such as neutropenia, gastrointestinal adverse events, and tumor lysis syndrome (TLS). The risk of TLS can be reduced by a slow dose ramp-up, strict monitoring, and adequate prophylaxis $[1,2,3]$.

An 86-year-old female patient presented to the hospital with fatigue, weight loss, night sweats, shortness of breath, and weakness. She had been diagnosed with CLL 10 years previously and she subsequently received four lines of chemoimmunotherapy. During the COVID-19 pandemic she did not visit the hospital for CLL follow-up. Her white blood cell count was $925,190 / \mu \mathrm{L}$ with $90 \%$ lymphocytes. Hemoglobin level was $5.2 \mathrm{~g} / \mathrm{dL}$ and platelet count was $128,000 / \mu \mathrm{L}$. Lymphocytes expressed CD5, CD19, CD23, CD200, and CD20. Other laboratory investigations including urea, electrolytes, and liver function tests were all within normal limits. In computed tomography scans of the neck, thorax, abdomen, and pelvis, she was observed to have splenomegaly $(150 \mathrm{~mm})$ and paraaortic, supraclavicular, axillar, and mediastinal multiple, differently sized (32x21 to $22 \times 13 \mathrm{~mm}$ ) lymphadenopathies. Venetoclax treatment was planned with a 5-week dosing ramp-up $(20 \mathrm{mg}, 50 \mathrm{mg}$, $100 \mathrm{mg}, 200 \mathrm{mg}, 400 \mathrm{mg}$ ) with adequate tumor lysis prophylaxis (allopurinol and 1.5-2 L of fluid daily) and close monitoring. In the third week, COVID-19 infection was detected. The venetoclax treatment was continued without any change and the patient was discharged with no complications. Data obtained from laboratory monitoring are presented in Figure 1.

We observed rapid tumor debulking without complications and the disappearance of symptoms probably caused by venetoclaxinduced apoptosis. We conclude that venetoclax is an effective and safe treatment option for CLL $[4,5,6]$.

Keywords: Chronic lymphocytic leukemia, Venetoclax, Highest white blood cell count

Anahtar Sözcükler: Kronik lenfositik lösemi, Venetoclax, En yüksek beyaz küre sayısı 


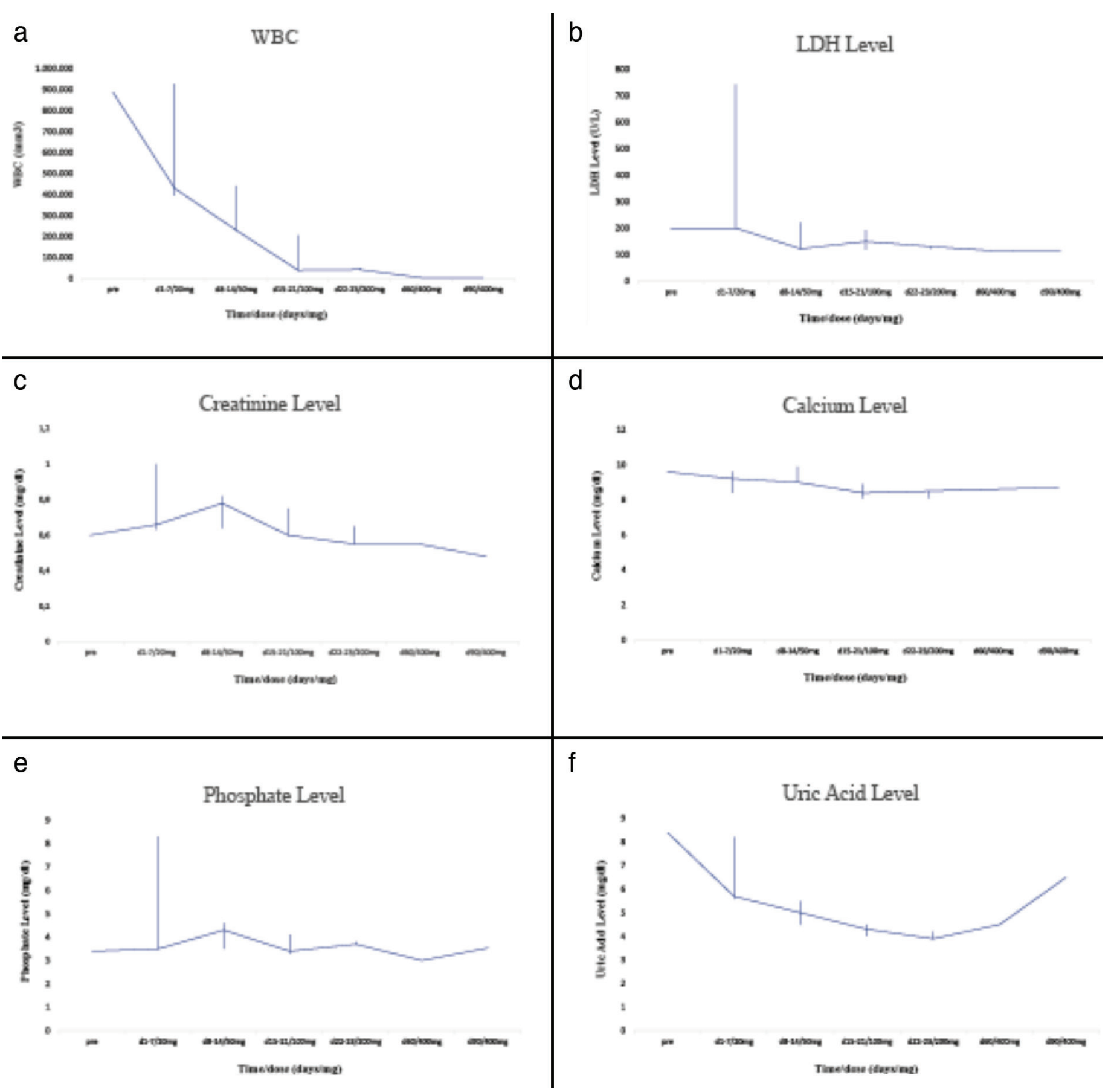

Figure 1. Trends of tumor lysis syndrome parameters during the first 3 months of treatment. Changes of (a) white blood cell (WBC), (b) lactate dehydrogenase (LDH), (c) creatinine, (d) calcium, (e) phosphate, and (f) uric acid levels. 


\section{Authorship Contributions}

Design: M.S., O.A., N.E., Ö.B.; Data Collection or Processing: M.K.; Analysis or Interpretation: M.S., M.K., O.A., N.E., Ö.B.; Literature Search: M.S., M.K., O.A., N.E., Ö.B.; Writing: M.S., M.K.

Conflict of Interest: No conflict of interest was declared by the authors.

Financial Disclosure: The authors declared that this study received no financial support.

\section{References}

1. Eradat $\mathrm{H}$. Venetoclax for the treatment of chronic lymphocytic leukemia. Curr Hematol Malig Rep 2019;14:469-476.

2. Molica S. Venetoclax: a real game changer in treatment of chronic lymphocytic leukemia. Int J Hematol Oncol 2020;9:IJH31.

3. Roberts AW. Therapeutic development and current uses of BCL-2 inhibition. Hematology Am Soc Hematol Educ Program 2020;2020:1-9.
4. Fürstenau $M$, Langerbeins $P$, De Silva $N$, Fink $A M$, Robrecht $S$, von Tresckow J, Simon F, Hohloch K, Droogendijk J, van der Klift M, van der Spek E, IIImer T, Schöttker B, Fischer K, Wendtner CM, Tausch E, Stilgenbauer S, Niemann CU, Gregor M, Kater AP, Hallek M, Eichhorst B. COVID-19 among fit patients with CLL treated with venetoclax-based combinations. Leukemia 2020;34:2225-2229.

5. Mato AR, Thompson M, Allan JN, Brander DM, Pagel JM, Ujjani CS, Hill BT,

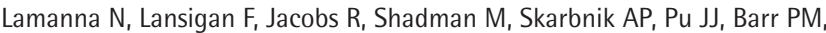
Sehgal AR, Cheson BD, Zent CS, Tuncer HH, Schuster SJ, Pickens PV, Shah NN, Goy A, Winter AM, Garcia C, Kennard K, Isaac K, Dorsey C, Gashonia LM, Singavi AK, Roeker LE, Zelenetz A, Williams A, Howlett C, Weissbrot $H_{\text {, }}$ Ali N, Khajavian S, Sitlinger A, Tranchito E, Rhodes J, Felsenfeld J, Bailey N, Patel B, Burns TF, Yacur M, Malhotra M, Svoboda J, Furman RR, Nabhan C. Real-world outcomes and management strategies for venetoclax-treated chronic lymphocytic leukemia patients in the United States. Haematologica 2018;103:1511-1517.

6. Koenig KL, Huang Y, Dotson EK, Sheredy S, Bhat SA, Byrd JC, Desmond E, Ford J, larocci S, Jones JA, Lucas MS, Moran ME, Wiczer TE, Woyach JA, Awan FT, Rogers KA. Safety of venetoclax rapid dose escalation in CLL patients previously treated with B-cell receptor signaling antagonists. Blood Adv 2020;4:4860-4863. 